Marquette University

e-Publications@Marquette

School of Dentistry Faculty Research and

Publications

Dentistry, School of

$3-2015$

\title{
In vivo Assessments of Bioabsorbable AZ91 Magnesium Implants Coated with Nanostructured Fluoridated Hydroxyapatite by MAO/ EPD Technique for Biomedical Applications
}

\author{
Mehdi Razavi \\ Oklahoma State University \\ Mohammadhossein Fathi \\ Isfahan University of Medical Sciences \\ Omid Savabi \\ Isfahan University of Medical Sciences \\ Daryoosh Vashaee \\ Oklahoma State University \\ Lobat Tayebi \\ Marquette University, lobat.tayebi@marquette.edu
}

Follow this and additional works at: https://epublications.marquette.edu/dentistry_fac

Part of the Dentistry Commons

\section{Recommended Citation}

Razavi, Mehdi; Fathi, Mohammadhossein; Savabi, Omid; Vashaee, Daryoosh; and Tayebi, Lobat, "In vivo Assessments of Bioabsorbable AZ91 Magnesium Implants Coated with Nanostructured Fluoridated Hydroxyapatite by MAO/EPD Technique for Biomedical Applications" (2015). School of Dentistry Faculty Research and Publications. 165.

https://epublications.marquette.edu/dentistry_fac/165 


\title{
In vivo Assessments of Bioabsorbable AZ91 Magnesium Implants Coated with Nanostructured Fluoridated Hydroxyapatite by MAO/EPD Technique for Biomedical Applications
}

\author{
Mehdi Razavi \\ Biomaterials Research Group, Department of Materials \\ Engineering, Isfahan University of Technology, \\ Dental Materials Research Center, \\ Isfahan University of Medical Sciences, \\ Torabinejad Dental Research Center, School of Dentistry, Isfahan \\ University of Medical Sciences, \\ Isfahan, Iran \\ School of Materials Science and Engineering, Helmerich \\ Advanced Technology Research Center, \\ Oklahoma State University, \\ Tulsa, OK
}

Materials Science and Engineering: C, Vol 48 (March 2015): pg. 21-27. DOI. This article is (C) Elsevier and permission has been granted for this version to appear in e-Publications@Marquette. Elsevier does not grant permission for this article to be further copied/distributed or hosted elsewhere without the express permission from Elsevier. 


\author{
Mohammadhossein Fathi \\ Biomaterials Research Group, Department of Materials \\ Engineering, Isfahan University of Technology, \\ Dental Materials Research Center, \\ Isfahan University of Medical Sciences, \\ Isfahan, Iran \\ Omid Savabi \\ Torabinejad Dental Research Center, School of Dentistry, \\ Isfahan University of Medical Sciences, \\ Isfahan, Iran \\ Daryoosh Vashaee \\ School of Electrical and Computer Engineering, Helmerich \\ Advanced Technology Research Center, \\ Oklahoma State University, \\ Tulsa, OK \\ Lobat Tayebi \\ School of Materials Science and Engineering, \\ Helmerich Advanced Technology Research Center, \\ Oklahoma State University, \\ Tulsa, OK \\ School of Dentistry, Department of Developmental Sciences, \\ Marquette University, \\ Milwaukee, WI \\ Biomaterials and Advanced Drug Delivery Laboratory, \\ Stanford University, \\ Stanford, $C A$
}

\begin{abstract}
Although magnesium $(\mathrm{Mg})$ is a unique biodegradable metal which possesses mechanical property similar to that of the natural bone and can be an attractive material to be used as orthopedic implants, its quick corrosion rate restricts its actual clinical applications. To control its rapid degradation, we have modified the surface of magnesium implant using fluoridated hydroxyapatite (FHA: $\left.\mathrm{Ca}_{10}\left(\mathrm{PO}_{4}\right)_{6} \mathrm{OH}_{2}-{ }_{x} \mathrm{~F}_{\mathrm{x}}\right)$ through the combined micro-arc oxidation (MAO) and electrophoretic deposition (EPD) techniques, which was

Materials Science and Engineering: C, Vol 48 (March 2015): pg. 21-27. DOI. This article is @ Elsevier and permission has been granted for this version to appear in e-Publications@Marquette. Elsevier does not grant permission for this article to be further copied/distributed or hosted elsewhere without the express permission from Elsevier.
\end{abstract}


presented in our previous paper. In this article, the biocompatibility examinations were conducted on the coated AZ91 magnesium alloy by implanting it into the greater trochanter area of rabbits. The results of the in vivo animal test revealed a significant enhancement in the biocompatibility of FHA/MAO coated implant compared to the uncoated one. By applying the FHA/MAO coating on the AZ91 implant, the amount of weight loss and magnesium ion release in blood plasma decreased. According to the histological results, the formation of the new bone increased and the inflammation decreased around the implant. In addition, the implantation of the uncoated AZ91 alloy accompanied by the release of hydrogen gas around the implant; this release was suppressed by applying the coated implant. Our study exemplifies that the surface coating of magnesium implant using a bioactive ceramic such as fluoridated hydroxyapatite may improve the biocompatibility of the implant to make it suitable as a commercialized biomedical product.

Keywords: Bioabsorbable magnesium alloy, Coating, Surface modification, Fluoridated hydroxyapatite, in vivo

\section{Introduction}

Bio-metals such as titanium alloys and stainless steels have been commonly utilized as orthopedic implants due to their mechanical strength. ${ }^{1}$ However, mechanical properties of these materials vary vastly from those of the human bone, which may lead to the "stressshielding" problem. ${ }^{2}$ Moreover, the corrosion products of some of these alloys may cause long-standing unfavorable effects. ${ }^{1}$ Since the metal implants are used as permanent devices such as pins, screws, nails and bone plates, they remain as a foreign body to the host tissues even after the completion of healing process, and may need to be extracted by a post-surgical procedure. The second surgery not only increases the health care cost, but it may contribute to the patient's morbidity. ${ }^{3}$

Absorbable biocompatible materials may be a proper solution since they eventually dissolve in body fluid.4,5 Several polymers, ceramics and nanocomposites have been developed as degradable biomedical materials. ${ }^{6,7}$ However, they lack appropriate mechanical properties and cannot be used for load-bearing applications. ${ }^{2,8}$ Magnesium ( $\mathrm{Mg}$ ) and its alloys have recently been known as a bioabsorbable bone implant materials, since they possess mechanical properties similar to those of the human bone with an appropriate biocompatibility. ${ }^{9,10}$ However, in spite of the advantages of magnesium

Materials Science and Engineering: C, Vol 48 (March 2015): pg. 21-27. DOI. This article is (C) Elsevier and permission has been granted for this version to appear in e-Publications@Marquette. Elsevier does not grant permission for this article to be further copied/distributed or hosted elsewhere without the express permission from Elsevier. 
alloys, they have not been commercialized yet. ${ }^{11}$ The foremost drawback reported for magnesium alloys has been related to their high corrosion rate in the physiological environment. ${ }^{12,13}$ For that reason, an initially low or ideally a controllable absorbable rate is wanted to avoid further deterioration of the adjacent tissue. ${ }^{14,15}$

If the magnesium implants are being used to fix damage bone tissue, they are likely to lose their mechanical integrity earlier than tissue healing of bone due to their rapid corrosion and low bioactivity. ${ }^{16,17}$ Recently, some research has been planned to slow down the corrosion rate of magnesium alloys. ${ }^{18,19}$ Surface modification and coating by various materials has been employed as a proper approach for controlling the corrosion properties of metals since decades ago with excellent rate of success. ${ }^{20,21}$ The reduction of the corrosion rate of magnesium alloys may also be achieved by appropriate surface treatment. ${ }^{22,23}$ If the coating material is bioactive, it not only decreases the corrosion rate, but it can also improve the biocompatibility which is necessary for the use of magnesium alloys. ${ }^{24}$

Hydroxyapatite (HA) with the chemical composition of $\mathrm{Ca}_{10}\left(\mathrm{PO}_{4}\right)_{6}(\mathrm{OH})_{2}$ has been extensively used as bioactive coating materials for hard tissue devices. The replacement of $\mathrm{F}^{-}$ion instead of $\mathrm{OH}^{-}$group in $\mathrm{HA}$ composition gives a bioactive ceramic with the chemical composition of $\mathrm{Ca}_{10}\left(\mathrm{PO}_{4}\right)_{6} \mathrm{OH}_{2}-{ }_{x} \mathrm{~F}_{x}$; where $\mathrm{x}$ stands for the degree of fluoridation which is called fluoridated hydroxyapatite (FHA). FHA is beneficial to improve some key properties of $H A$; it has lower absorbable rate and better bioactivity compared to $\mathrm{HA}$, and hence FHA has the potential to be used as a decent coating material for bioabsorbable magnesium alloys. ${ }^{25,26}$

In addition, the biological properties of a coating may be improved if it is made in nanostructural configuration similar to the structure of natural bone. ${ }^{27}$ Thus, in this paper, we planned to prepare a nanostructured FHA coating on Mg alloy implants. Electrophoretic deposition (EPD) is known as an inexpensive and easily applicable method of coating that has been broadly used for surface coating of bioactive ceramics on metallic implants including stainless steels, cobalt and titanium alloys. ${ }^{28}$ In this paper, we utilized EPD technique for coating of the FHA layer. However, EPD would be more effective if it applied on a porous structure. Thus, as an intermediate layer on the

Materials Science and Engineering: C, Vol 48 (March 2015): pg. 21-27. DOI. This article is @ Elsevier and permission has been granted for this version to appear in e-Publications@Marquette. Elsevier does not grant permission for this article to be further copied/distributed or hosted elsewhere without the express permission from Elsevier. 
magnesium alloys, micro-arc oxidation (MAO) has been introduced on the surface of the $\mathrm{Mg}$ substrate. It not only can produce a porous template for the EPD coating layer, but it also can act as a barrier layer for corrosion attacks due to the existence of $\mathrm{MgO}$ in its chemical composition. 22,29

There has been some research separately on MAO coating, ${ }^{29,30,31}$ and FHA coating by electrodeposition technique ${ }^{32,33}$ on magnesium alloys. In our previous work, we employed a combination of MAO and EPD techniques for the surface modification of AZ91 magnesium alloy by FHA coating which exhibits a significant property enhancement of implants. The coating performance, the bioactivity, and the corrosion resistance have been discussed in our previous paper. ${ }^{34}$ In this article, we have developed our analysis on the in vitro and in vivo biocompatibility of FHA/MAO coated implants in comparison with both MAO coated and uncoated AZ91 substrates.

\section{Materials and methods}

Preparation of FHA/MAO coating on AZ91 magnesium alloy substrates was explicitly explained in our previously published work in which the detailed study on the fabrication, characterization, corrosion behavior and bioactivity of the samples was presented. ${ }^{34}$ Briefly, plate samples with dimensions of $20 \times 15 \times 5 \mathrm{~mm}^{3}$ were cut from an AZ91 magnesium alloy ingot. Afterward, they were ground with SiC papers to 600 grits and then were sonicated in acetone. The FHA powder was prepared using sol-gel technique. To prepare FHA, $1.227 \mathrm{~g}$ of phosphorous pentoxide $\left(\mathrm{P}_{2} \mathrm{O}_{5}\right)$ was added into a beaker containing $20 \mathrm{~mL}$ ethanol. Another solution including $7 \mathrm{~g}$ calcium nitrate tetrahydrate $\left(\mathrm{Ca}\left(\mathrm{NO}_{3}\right)_{2} \cdot 4 \mathrm{H}_{2} \mathrm{O}\right.$, Merck) and $20 \mathrm{~mL}$ of absolute ethanol was prepared separately and added to the previous solution. For incorporation of fluorine ion, $70.28 \mu$ l hexafluorophosphoric acid ( $\left.\mathrm{HPF}_{6}\right)$ was added into the mixture. The mixture was stirred for about $20 \mathrm{~h}$ to form a viscous gel. The gel was dried in an oven and heat treated at $600{ }^{\circ} \mathrm{C}$ for $1 \mathrm{~h}$. The produced powders were milled for $10 \mathrm{~h}$ with the ball/powder ratio of $10 / 1$ and rotational speed of $250 \mathrm{rpm}$ to achieve the nanostructured FHA powder.

The MAO process was conducted on a direct current (DC) power supply. The prepared AZ91 samples and a stainless steel plate were

Materials Science and Engineering: C, Vol 48 (March 2015): pg. 21-27. DOI. This article is (C) Elsevier and permission has been granted for this version to appear in e-Publications@Marquette. Elsevier does not grant permission for this article to be further copied/distributed or hosted elsewhere without the express permission from Elsevier. 
placed as the anode and cathode respectively inside an electrolyte solution composed of $200 \mathrm{~g} / \mathrm{L} \mathrm{Na}_{2} \mathrm{SiO}_{3}$ and $200 \mathrm{~g} / \mathrm{L} \mathrm{NaOH}$. The voltage was applied step by step to reach $60 \mathrm{~V}$ for half an hour. The coated samples were removed from the electrolyte solution, cleaned with acetone and dried at room temperature which was approximately $25^{\circ} \mathrm{C}$.

To perform the EPD process, the powder was used in asreceived condition to produce EPD suspension containing $100 \mathrm{~g} / \mathrm{L}$ of FHA particles in methanol. The dispersion process was carried out using ultrasonication and magnetic stirring. In order to disperse the particles inside the solution, the prepared suspension was placed into an ultrasonic bath for about $20 \mathrm{~min}$. Afterwards, the dispersion process was carried out using magnetic stirring. The MAO sample and a graphite rod were placed at the location of cathode and anode, respectively. Electrophoretic deposition was started by setting the constant voltage at $100 \mathrm{~V}$, deposition time of $3 \mathrm{~min}$ and electrode separation of $2 \mathrm{~cm}$.

The size of produced FHA nanoparticles was measured using a transmission electron microscope (TEM: JEOL JEM-2100). The surface crystal structure of the samples (before and after the immersion test) was analyzed using a scanning electron microscope (SEM: Philips XL 30: Eindhoven) equipped with energy-dispersive $X$-ray spectroscopy (EDX). A laser scanning microscope (Keyence, VK X100/X200), equipped with a VK analyzer was used in order to observe the surface of coated samples. An adhesion tester (PosiTest AT-A, USA) was employed to determine the adherence strength of coatings on the substrate.

During the cell culture test, cell viability, $\mathrm{pH}$ values and $\mathrm{Mg}$ ion release of samples in the culture media were measured. For cell viability evaluation, L-929 cell line was cultured in $89 \%$ Dulbecco's modified Eagle's medium (DMEM, Gibco) supplemented with $10 \%$ fetal bovine serum (FBS, Gibco) and 1\% penicillin streptomycin. The samples were sterilized and the cells were seeded onto the samples. Cell viability was evaluated after 2, 5, and 7 days of culture times. For this purpose, at each time point, the medium was replaced by MTT solution and the samples were incubated in this solution for $4 \mathrm{~h}$. Finally, the medium was replaced by dimethylsulfoxide (DMSO). A 
microplate reader measured the absorbance of samples. The cell viability was expressed as $O D_{\text {sample }} / O D_{\text {control }} * 100 \%$, where $O D_{\text {sample }}$ and $\mathrm{OD}_{\text {control }}$ were the optical density of the sample and the control, respectively. For the control group, cells were cultured on tissue culture polystyrene plate filled with DMED. In addition, the $\mathrm{pH}$ values and the $\mathrm{Mg}$ ion concentrations of the medium were evaluated. Analysis of variance (ANOVA) was performed for the statistical analysis and the statistical significance was defined as $p<0.05$.

For in vivo animal examinations, the implants were machined in rod shape with $3 \mathrm{~mm}$ diameter and $6 \mathrm{~mm}$ length. Adult rabbits were used in our study and the surgical procedure was conducted according to the requirements of the University Ethics Committee in the Animal Unit. The rabbits were anesthetized with Ketamine, Xylazine and Acepromazine. After anesthesia, the operation site was shaved and decortication was carried out. A hand driller was utilized to make a hole of $3 \mathrm{~mm}$ diameter into the greater trochanter area of rabbits. The rod samples were implanted inside the holes and the wound was sutured layer-by-layer. All rabbits received an injection of antibiotics at the end of the operation. The rabbits were euthanized after 2 months. Meanwhile, the X-ray radiography and blood test were performed during this period. Then, the bone samples including the implants were taken out to detect the new bone formation around the implants via histological analysis. For this purpose, the bone samples were decalcified by nitric acid and were stained with Hematoxylin and Eosin (H\&E). A light microscope was utilized to observe the changes in bone structure around the implants.

\section{Results and discussion}

As can be seen in the TEM image of Fig. 1a, the size of the FHA nanoparticles are in the range of 50-100 nm with agglomerative configuration. The XRD pattern of nanoparticles in Fig. $1 \mathrm{~b}$ represents the expected crystallized peaks of FHA. According to SEM image of Fig. 1c, the surface of MAO coating has a rough morphology containing several pores. This structure was formed by releasing the gas bubbles in molten oxide during the arcs. XRD pattern of the MAO coating in Fig. $1 \mathrm{~d}$ detects $\mathrm{Mg}, \mathrm{MgO}$ and $\mathrm{Mg}_{2} \mathrm{SiO}_{4}$ peaks in the $\mathrm{MAO}$ coating. $\mathrm{MgO}$ is formed by dissolving $\mathrm{Mg}^{2}+$ from the AZ91 substrate and its chemical

Materials Science and Engineering: C, Vol 48 (March 2015): pg. 21-27. DOI. This article is (C) Elsevier and permission has been granted for this version to appear in e-Publications@Marquette. Elsevier does not grant permission for this article to be further copied/distributed or hosted elsewhere without the express permission from Elsevier. 
reaction with the $\mathrm{O}^{2}$ - from the electrolyte. At higher temperature during the micro-arc oxidation process, both $\mathrm{SiO}_{2}$ and $\mathrm{MgO}$ are presented and form $\mathrm{Mg}_{2} \mathrm{SiO}_{4}$ (forsterite). $\mathrm{MgO}$ and $\mathrm{Mg}_{2} \mathrm{SiO}_{4}$ protect the substrate from the corrosion attacks and have positive effects on enhancing the bioactivity. The surface morphology of the FHA coating is illustrated in Fig. 1e. According to the SEM micrograph of FHA coating in this figure, it has a porous surface with a netlike structure. It has been suggested that this configuration can be supportive for cell attachment and proliferation, and may improve the biological fixation of the implant to the surrounding bone tissue. As can be seen in the XRD pattern of FHA coating in Fig. 1f, besides the diffraction peaks from the MAO ( $\mathrm{Mg}, \mathrm{MgO}$ and $\mathrm{Mg}_{2} \mathrm{SiO}_{4}$ ), the diffraction peaks from FHA were also detected, indicating that FHA has been coated as the main phase on the surface of MAO.

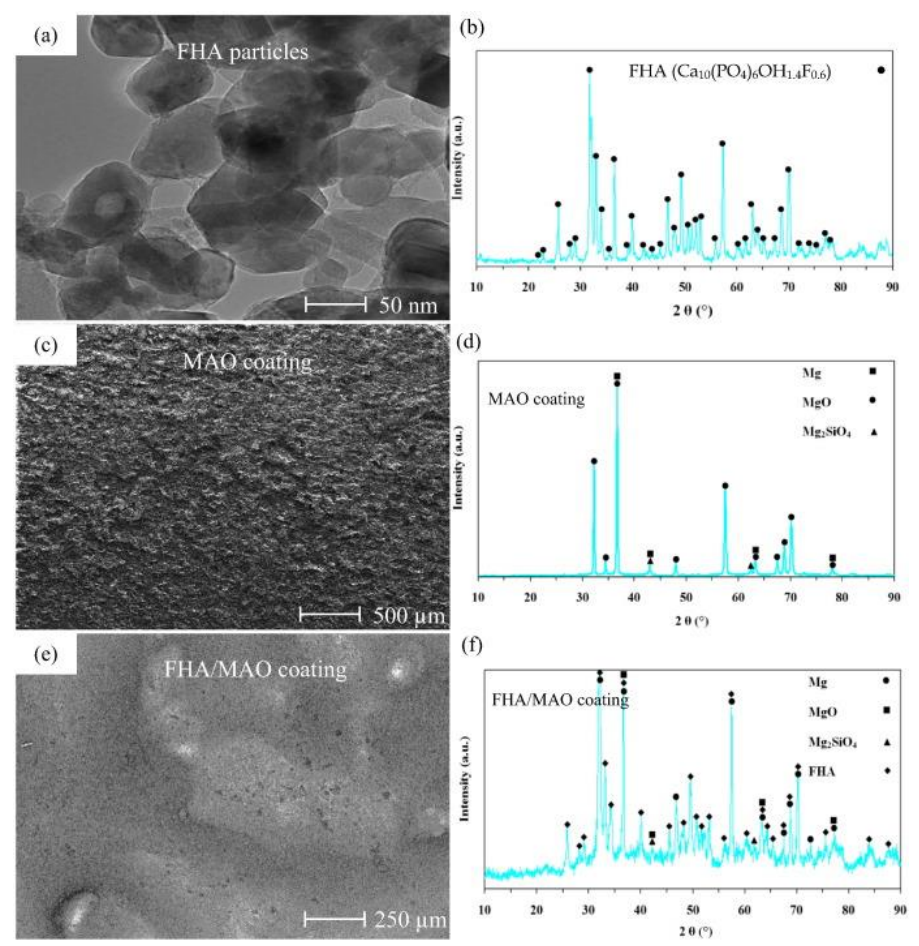

Fig. 1. TEM image of FHA particles (a), XRD pattern of FHA particles (d), SEM micrograph of MAO coating (c), XRD pattern of MAO coating (d), SEM micrograph of FHA coating (e), and XRD pattern of FHA coating ( $f)$.

The cross-sectional morphologies of the AZ91 (a), MAO (b) and FHA/MAO coated (c) samples have been presented in Fig. 2 which indicate that the thicknesses of MAO and FHA coating are approximately 100 and $250 \mu \mathrm{m}$, respectively. The FHA, with a rough 
morphology, has been deposited on the surface of MAO coating. Different phases including AZ91, MAO coating and FHA/MAO coating can be observed in SEM micrographs. The EDS line-scan analysis as an inset in Fig. 2c shows that the FHA coating mainly contains of $\mathrm{Ca}, \mathrm{Mg}$, and $\mathrm{P}$ elements. As can be seen in Fig. 2c, the intensities of $\mathrm{Ca}$ and $\mathrm{P}$ decrease and the intensity of $\mathrm{Mg}$ increases from FHA/MAO coating to the AZ91 substrate, as the coating layer contains Ca and P. According to the laser scanning microscopy images (Fig. 2d, e, f), the MAO coating has bumpy morphology compared to the AZ91 substrate with roughness of about $15 \mu \mathrm{m}$. The roughness of FHA/MAO coating is approximately $200 \mu \mathrm{m}$ which is significantly more than that of the MAO coating. Several islands (red color) with the approximate height of $500 \mu \mathrm{m}$ can be observed in Fig. 2f. Small submicron surface roughness can be observed on the FHA/MAO coating according to the line scan profilometry analysis (Fig. $2 \mathrm{i}$ ). The measured roughness values for red and blue islands are approximately 7 and $11 \mu \mathrm{m}$ for red and blue islands, respectively.
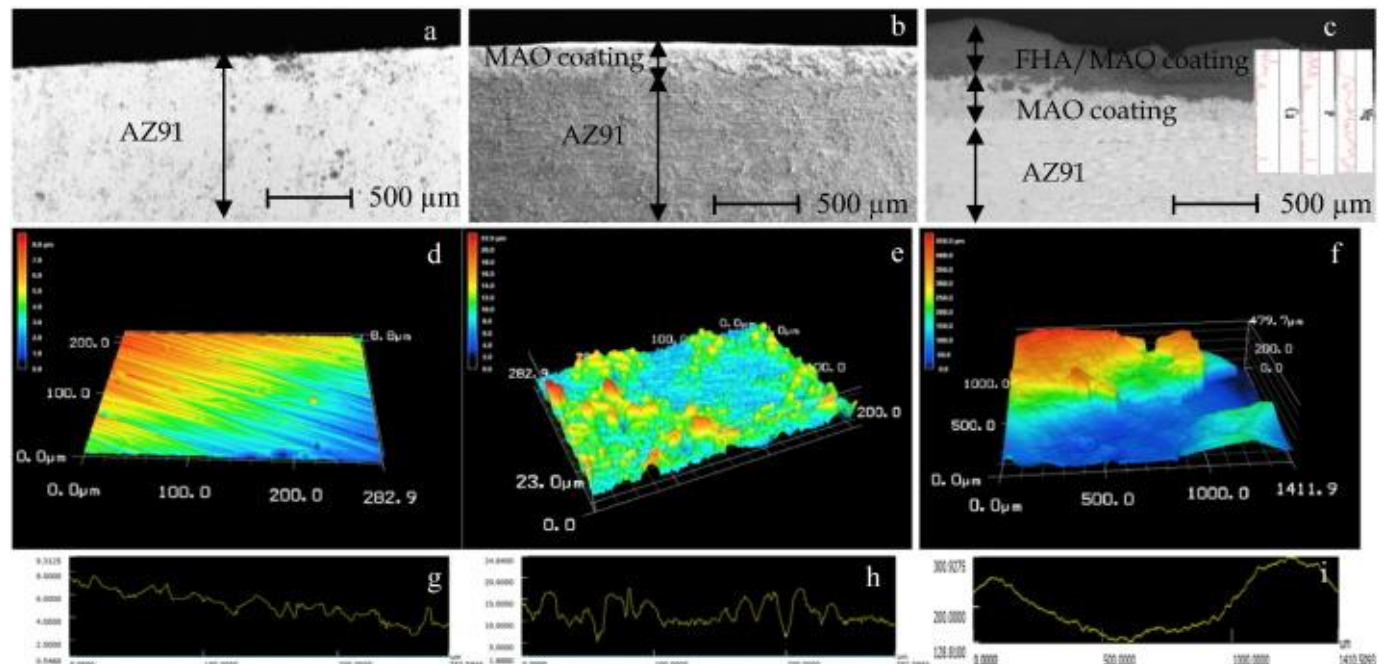

Fig. 2. Cross-sectional morphology of the $A Z 91$ (a), MAO (b) and FHA/MAO (c) coated samples, three dimensional laser scanning microscopy images of the AZ91 (d), MAO (e) and FHA/MAO (f) coated samples, and surface profilometry analysis of AZ91 (g), MAO (h) and FHA/MAO (i) coated samples.

Since the MAO coating has a high strength metallurgical binding with the AZ91 substrate, the adhesion tester was not able to measure the adherence strength. However, the adherence strength between the FHA/MAO coating and MAO coating was measured $6.5 \pm 0.3 \mathrm{MPa}$. 
Table 1 presents the results of the cell viability in 2, 5, and 7 days of culture times. For all samples, the cell viability increased with culture time. The cell viability of AZ91 sample increased from $50 \%$ after 2 days to $58 \%$ after 7 days of culture time. The cell viability of MAO sample increased from $70 \%$ after 2 days to $85 \%$ after 7 days of culture time and for FHA/MAO coated sample, the cell viability increased from $160 \%$ after 2 days of culture time to $175 \%$ after 7 days of incubation. Thus, the FHA/MAO coated sample presented a superior cell viability compared to others. This indicated that the coated samples have significantly more initial cytocompatibility than the uncoated sample. It is worth mentioning that the FHA/MAO coated sample has shown cell viability over $100 \%$ in all culture times. According to the cell viability calculation in the present study (cell viability $=O D_{\text {sample }} / O D_{\text {control }} \times 100$ ), the cell viability is over $100 \%$ when the optical density of a sample (OD sample) is more than that of the control group ( $O D_{\text {control }}$ ) which denotes that the sample possesses more viable cells compared to the control group confirming the good proliferation of cells on that sample. In the present study, the amount of cell viability of FHA/MAO coated sample (160\% after 2 days and $175 \%$ after 7 days) indicates that the sample was not cytotoxic, and the FHA/MAO coated sample facilitated the cell proliferation.

Table 1. The results of cell viability in 2, 5, and 7 days of culture times.

\begin{tabular}{llll}
$\quad$ Samples & \multicolumn{1}{c}{$\mathbf{2}$ (days) } & \multicolumn{1}{c}{$\mathbf{5}$ (days) } & $\mathbf{7}$ (days) \\
AZ91 magnesium alloy & $50 \pm 3$ & $55 \pm 5$ & $58 \pm 7 \%$ \\
MAO coating & $70 \pm 5$ & $80 \pm 6$ & $85 \pm 7 \%$ \\
FHA/MAO coating & $160 \pm 9$ & $170 \pm 10$ & $175 \pm 9 \%$
\end{tabular}

The $\mathrm{pH}$ values of DMEM culture medium during the cell culture test for AZ91, MAO, and FHA/MAO coated samples are shown in Fig. 3a. According to Fig. 3a, the $\mathrm{pH}$ value of AZ91 sample after 2 days was 8.8 which reached 9.5 after 7 days. The $\mathrm{pH}$ value of MAO sample after 2 days and 7 days was 8.1 and 8.8, respectively. For the FHA/MAO coated sample, the pH value changed from 7.8 after 2 days to 8.1 after 7 days. The $\mathrm{pH}$ increase is mostly as a result of the releasing the $\mathrm{OH}^{-}$group in the medium. The less increase of $\mathrm{pH}$ value of the medium containing the MAO and FHA/MAO coated sample for the period of the cell culture shows a comparatively slow corrosion and an improvement of the corrosion resistance of MAO and FHA/MAO coating. Fig. $3 \mathrm{~b}$ shows the $\mathrm{Mg}$ ion release of the samples during the 
cell culture test. According to Fig. 3b, the $\mathrm{Mg}$ ion concentration after 2 days for AZ91, MAO, and FHA/MAO coated samples was 22, 18, and $13 \mathrm{ppm}$, respectively. After 7 days, the $\mathrm{Mg}$ ion concentration increased to 30,25 , and $17 \mathrm{ppm}$ for AZ91, MAO, and FHA/MAO coated samples, respectively. Thus, according to the results, for all samples the $\mathrm{Mg}$ ion concentration increased with the culture time, however, the lowest $\mathrm{Mg}$ ion concentration was found for FHA/MAO coated samples indicating the least corrosion rate compared to the others.
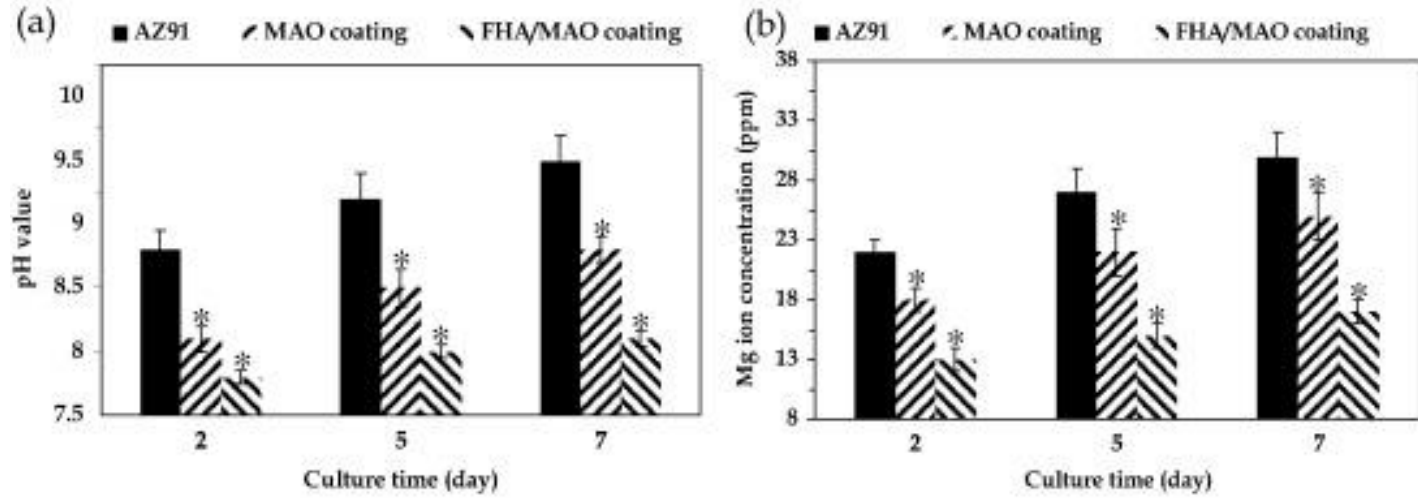

Fig. 3. $\mathrm{pH}$ values of DMEM culture medium (a) and $\mathrm{Mg}$ ion release (b) of $A Z 91, M A O$, and $\mathrm{FHA} / \mathrm{MAO}$ coated samples during the cell culture test in DMEM culture medium showing the corrosion behavior of samples during the cell culture test.

The environmental variations including $\mathrm{pH}$ changes and $\mathrm{Mg}$ ion release in the culture medium affect the cell viability. The fast increase of $\mathrm{pH}$ value leads to less viability and proliferation of cells. In addition, $\mathrm{Mg}$ ion release is accompanied by the production of hydrogen bubbles from the surface. The hydrogen evolution can be an important obstacle for cell attachment. ${ }^{35}$ The surface modification of magnesium substrate can significantly decrease the corrosion rate leading to less change in $\mathrm{pH}$ value and $\mathrm{Mg}$ ion release. ${ }^{33}$ In our study, $\mathrm{FHA} / \mathrm{MAO}$ coating on the magnesium substrate reduces the $\mathrm{pH}$ increase and $\mathrm{Mg}$ ion release leads to the best cell viability compared to other samples. Moreover, having calcium element in the chemical composition of FHA coating can be helpful on the cellular behavior, as it improves the chemical signaling of the cells and absorbs fibronectin and vitronectin proteins which are crucial elements on the biological function of the cells. ${ }^{36}$

The AZ91 (a), MAO (d), and FHA/MAO coated (g) samples were implanted into the greater trochanter of rabbits and the surgery images are presented in Fig. 4. According to the post-operation 
veterinary examinations, clinical signs as a result of swelling, pain or alteration were not detected. The formation of gas bubbles below the skin was not detected and good wound healing was observed after the surgery. The X-ray radiography images from AZ91 (Fig. 4b), MAO (Fig. 4e) and FHA/MAO coated (Fig. 4h) implants were taken off the rabbits 2 weeks after the surgery. The gas bubbles around the AZ91 implants (black area) were more than other implants due to the higher corrosion rate, however, almost no gas bubbles were found around the FHA/MAO coated implants. Note that the absorption of hydrogen gas usually occurs in longer times as a result of decreasing the corrosion rate due to the formation of corrosion products on the surface. ${ }^{35}$ Other researchers have also mentioned that the visible subcutaneous hydrogen bubbles appeared in the first days after the surgery and disappeared after 2-3 weeks. ${ }^{37}$ After euthanizing the rabbits, pathological examinations were carried out on the bone tissue around implantation region of the AZ91 (Fig. 4C), MAO (Fig. 4f), and FHA/MAO coated (Fig. 4i) implants. Comparing the histological images of different samples, one may notice that the new bone formed around the FHA/MAO coated implants was more than the others and conversely the inflammation was less than others. The level of the volume percentage of new bone formation around the implants was in the following order: FHA/MAO coating (60\%) > MAO (31\%) > AZ91 (27\%). Lower release of hydrogen bubbles around the FHA/MAO coated implants due to the lower corrosion rate led to the more bone formation and less inflammation compared to other samples.

Furthermore, the existence of $\mathrm{Ca}$ and $\mathrm{P}$ elements in the chemical composition of FHA can stimulate the osteoblastic cells and improve the osteoconductivity. ${ }^{24}$ Immune response to implants generally comprises the hypersensitivity related to implants. ${ }^{38}$ Observation of hypersensitivity reactions in surrounding tissues upon discharging the corrosion products suggests that there is a correlation between corrosion and metal hypersensitivity. ${ }^{39}$ Moreover, metals suffering from wear process release wear particles which may provoke undesirable reactions in patients and cause inflammation which consequently may loosen the implant. ${ }^{40}$ Phagocytic cells take up corrosion products and particles, and generate pro-inflammatory cytokines. The inflammation endures by releasing more particles from the implant, and possibly by self-perpetuating cytokine-driven procedures. The pro-inflammatory surrounding stimulates the 
generation of bone resorbing cells, and consequently the patient may experience severe bone loss and implant loosening, followed by pain and limitation of motion as symptoms of metallosis. ${ }^{41}$ Although, the microscopic inflammation could be observed in the bone tissue around the implants of our experiment according to histological images, there was no sign of macroscopic inflammations in veterinary examinations.
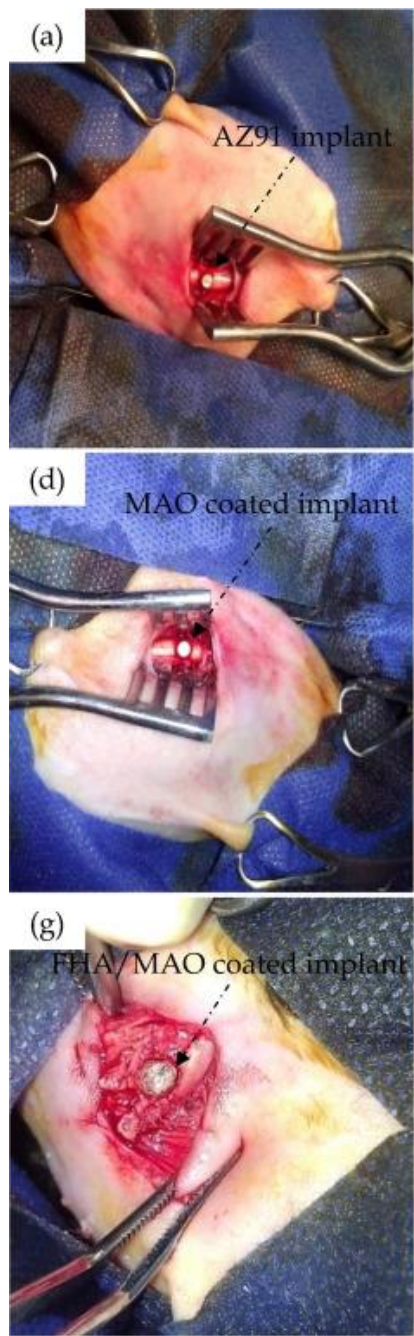

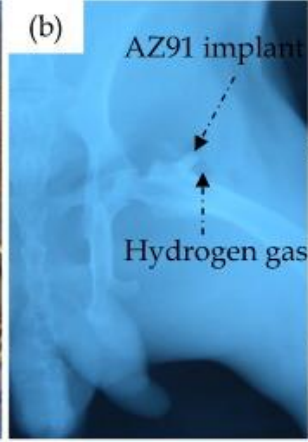

(e)

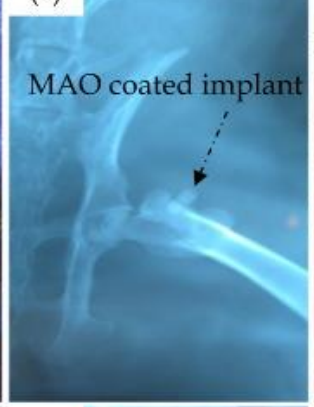

(h)

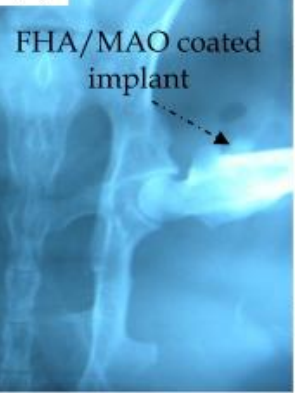

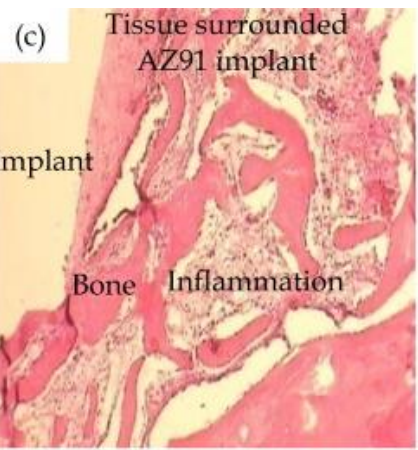
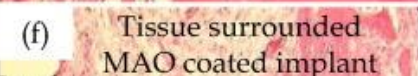
Implant

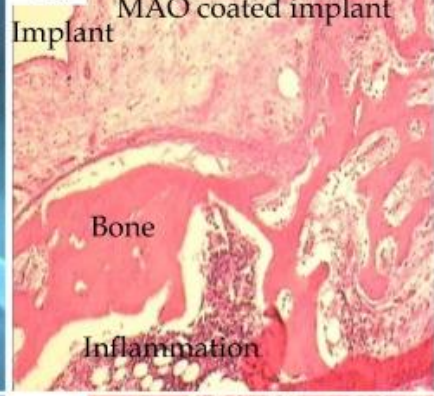

(i) Tissue surrounded

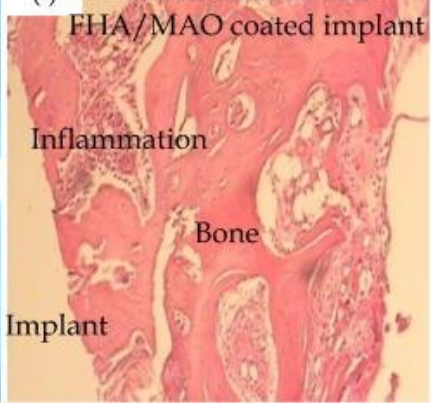

Fig. 4. The surgery images of $A Z 91$ (a), MAO (d), and FHA/MAO coated ( $g$ ) samples, the X-ray radiography images from AZ91 (b), MAO (e), and FHA/MAO coated (h) samples and the histological analysis of AZ91 (c), MAO (f), and FHA/MAO coated (i) samples implanted into the greater trochanter of rabbits.

The results of the blood test to detect the changes of serum magnesium level in blood plasma for AZ91, MAO, and FHA/MAO coated implants before implantation and after 2 weeks, 1 and 2 months of post-operation are presented in Fig. 5. Before the surgery, the serum 
magnesium value was the same for all rabbits. Although it increased due to the corrosion of magnesium substrate, it was within the normal range of physiological magnesium level (20 ppm). ${ }^{42}$ However, according to the results, the difference between serum magnesium value before and after the surgery for FHA/MAO coated implants was less than others.

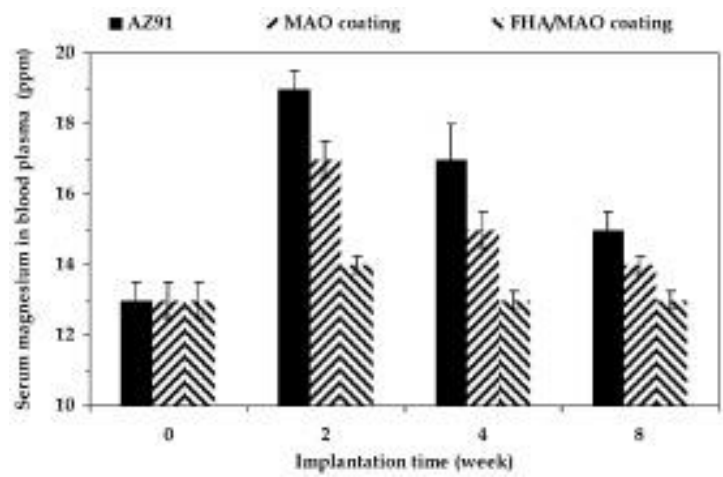

Fig. 5. The results of the blood test to detect the changes of serum magnesium level in blood plasma for AZ91, MAO, and FHA/MAO coated implants before implantation and after 2 weeks, 1 and 2 months of post-operation.

The weight variation of implants after euthanizing the rabbits was measured. The results indicated that the weight losses of $A Z 91$, MAO, and FHA/MAO coated implants were 25,16 , and $4 \mathrm{mg} / \mathrm{cm}^{2}$, respectively. Thus, the weight loss of the FHA/MAO coated implant was significantly less than that of the other implants. It is worth noting that a large amount of magnesium ions is released during the corrosion of implants. However, no considerable increase is observed in the serum magnesium value. This may be due to the regulation of magnesium ions in the kidney and their excretion in the urine. ${ }^{24}$

\section{Conclusion}

In order to enhance the corrosion resistance of magnesium implants, we have modified the surface of AZ91 magnesium alloy using fluoridated hydroxyapatite through the micro-arc oxidation/electrophoretic deposition (MAO/EPD) technique. In continuation with our previous work, we completed our study on the coated and uncoated $\mathrm{Mg}$ implants by biocompatibility analyses including in vivo examinations. The results confirmed that the FHA/MAO coating noticeably improved the biocompatibility of AZ91

Materials Science and Engineering: C, Vol 48 (March 2015): pg. 21-27. DOI. This article is (C) Elsevier and permission has been granted for this version to appear in e-Publications@Marquette. Elsevier does not grant permission for this article to be further copied/distributed or hosted elsewhere without the express permission from Elsevier. 
NOT THE PUBLISHED VERSION; this is the author's final, peer-reviewed manuscript. The published version may be accessed by following the link in the citation at the bottom of the page.

magnesium alloy implant. Thus, we recommend the bioabsorbable FHA/MAO coated Mg implant as a suitable candidate for future clinical orthopedic applications.

\section{Acknowledgment}

The authors are thankful for the contributions of Isfahan University of Technology, Torabinejad Dental Research Center, Oklahoma Center for Advancement of Science and Technology (Grant no. AR131-054 8161), AFOSR (Grant no. FA9550-10-1-0010) and the National Science Foundation (NSF, Grant no. 0933763).

\section{References}

${ }^{1}$ Y. Zheng, X. Gu, F. Witte. Mater. Sci. Eng. R. Rep., 77 (2014), pp. 1-34

${ }^{2}$ M.P. Staiger, A.M. Pietak, J. Huadmai, G. Dias. Biomaterials, 27 (2006), pp. 1728-1734

${ }^{3}$ N. Kirkland, N. Birbilis, M. Staiger. Acta Biomater., 8 (2012), pp. 925-936

${ }^{4}$ K.F. Farraro, K.E. Kim, S.L. Woo, J.R. Flowers, M.B. McCullough. J. Biomech., 47 (2013), pp. 1979-1986

${ }^{5}$ M. Razavi, M. Fathi, O. Savabi, B. Hashemi Beni, D. Vashaee, L.

Tayebi.Ceram. Int., 40 (2014), pp. 9473-9484

${ }^{6} \mathrm{M}$. Yazdimamaghani, D. Vashaee, S. Assefa, K. Walker, S. Madihally, G.

Köhler, L. Tayebi. J. Biomed. Nanotechnol., 10 (2014), pp. 911-931

${ }^{7}$ A. Shahini, M. Yazdimamaghani, K. Walker, M. Eastman, H. Hatami-Marbini, B. Smith, J. Ricci, S. Madihally, D. Vashaee, L. Tayebi. Int. J.

Nanomedicine, 9 (2014), pp. 167-181

${ }^{8}$ V. Shabafrooz, M. Mozafari, D. Vashaee, L. Tayebi. J. Nanosci. Nanotechnol., 14 (2014), pp. 522-534

${ }^{9}$ S. Virtanen. Mater. Sci. Eng. B, 176 (2011), pp. 1600-1608

10M. Razavi, M. Fathi, O. Savabi, D. Vashaee, L. Tayebi. Ann. Biomed. Eng. (2014), pp. 1-14

${ }^{11}$ F. Witte. Acta Biomater., 6 (2010), pp. 1680-1692

${ }^{12}$ M. Yazdimamaghani, M. Razavi, D. Vashaee, L. Tayebi. Mater. Lett., 132 (2014), pp. 106-110

${ }^{13}$ M. Razavi, M. Fathi, O. Savabi, S. Mohammad Razavi, B. Hashemi Beni, D. Vashaee, L. Tayebi. Mater. Lett., 113 (2013), pp. 174-178

${ }^{14}$ L. Xu, G. Yu, E. Zhang, F. Pan, K. Yang. J. Biomed. Mater. Res. A, 83 (2007), pp. 703-711

${ }^{15}$ M. Razavi, M. Fathi, O. Savabi, D. Vashaee, L. Tayebi. Mater. Sci. Eng. C, 41 (2014), pp. 168-177

${ }^{16}$ L. Tan, Q. Wang, X. Lin, P. Wan, G. Zhang, Q. Zhang, K. Yang. Acta Biomater., 10 (2014), pp. 2333-2340

Materials Science and Engineering: C, Vol 48 (March 2015): pg. 21-27. DOI. This article is (C) Elsevier and permission has been granted for this version to appear in e-Publications@Marquette. Elsevier does not grant permission for this article to be further copied/distributed or hosted elsewhere without the express permission from Elsevier 
NOT THE PUBLISHED VERSION; this is the author's final, peer-reviewed manuscript. The published version may be accessed by following the link in the citation at the bottom of the page.

${ }^{17}$ M. Razavi, M. Fathi, O. Savabi, S.M. Razavi, F. Heidari, M. Manshaei, D. Vashaee, L. Tayebi. Appl. Surf. Sci., 313 (2014), pp. 60-66

18M. Razavi, M. Fathi, O. Savabi, M. Boroni. Res. Rev. Mater. Sci. Chem., 1 (2012), pp. 15-58

${ }^{19}$ M. Razavi, M. Fathi, O. Savabi, D. Vashaee, L. Tayebi. Phys. Sci. Int. J., 4 (2014), pp. 708-722

${ }^{20}$ M. Yazdimamaghani, M. Razavi, D. Vashaee, L. Tayebi. Surf. Eng. (2014) http://dx.doi.org/10.1179/1743294414Y.0000000307

${ }^{21}$ M. Razavi, M. Fathi, O. Savabi, B.H. Beni, D. Vashaee, L. Tayebi. Colloids Surf. B: Biointerfaces, 117 (2014), pp. 432-440

${ }^{22} \mathrm{H}$. Hornberger, S. Virtanen, A. Boccaccini. Acta Biomater., 8 (2012), pp. 2442-2455

${ }^{23}$ M. Razavi, M. Fathi, O. Savabi, D. Vashaee, L. Tayebi. J. Biomed. Mater. Res. A (2014) http://dx.doi.org/10.1002/jbm.a.35324

${ }^{24}$ L. Xu, F. Pan, G. Yu, L. Yang, E. Zhang, K. Yang. Biomaterials, 30 (2009), pp. $1512-1523$

${ }^{25}$ A. Bianco, I. Cacciotti, M. Lombardi, L. Montanaro, E. Bemporad, M. Sebastiani. Ceram. Int., 36 (2010), pp. 313-322

${ }^{26}$ M. Razavi, M. Fathi, M. Meratian. Mater. Charact., 61 (2010), pp. 13631370

${ }^{27}$ T.J. Webster, R.W. Siegel, R. Bizios. Biomaterials, 20 (1999), pp. 12211227

${ }^{28}$ A. Boccaccini, S. Keim, R. Ma, Y. Li, I. Zhitomirsky. J. R. Soc. Interface, 7 (2010), pp. S581-S613

${ }^{29}$ M. Razavi, M. Fathi, O. Savabi, D. Vashaee, L. Tayebi. Annu. Res. Rev. Biol., 4 (2014), pp. 3716-3733

${ }^{30}$ X. Lin, L. Tan, Q. Zhang, K. Yang, Z. Hu, J. Qiu, Y. Cai. Acta Biomater., 9 (2013), pp. 8631-8642

${ }^{31}$ L. Zhao, C. Cui, Q. Wang, S. Bu. Corros. Sci., 52 (2010), pp. 2228-2234

32]. Li, P. Han, W. Ji, Y. Song, S. Zhang, Y. Chen, C. Zhao, F. Zhang, X. Zhang, Y. Jiang. Mater. Sci. Eng. B, 176 (2011), pp. 1785-1788

${ }^{33}$ Y. Song, S. Zhang, J. Li, C. Zhao, X. Zhang. Acta Biomater., 6 (2010), pp. 1736-1742

${ }^{34}$ M. Razavi, M. Fathi, O. Savabi, D. Vashaee, L. Tayebi. Surf. Eng., 30 (2014), pp. 545-551

${ }^{35}$ H.M. Wong, K.W. Yeung, K.O. Lam, V. Tam, P.K. Chu, K.D. Luk, K. Cheung. Biomaterials, 31 (2010), pp. 2084-2096

${ }^{36}$ B. Feng, J. Weng, B. Yang, S. Qu, X. Zhang. Biomaterials, 25 (2004), pp. 3421-3428

${ }^{37}$ F. Witte, V. Kaese, H. Haferkamp, E. Switzer, A. Meyer-Lindenberg, C. Wirth, H. Windhagen. Biomaterials, 26 (2005), pp. 3557-3563

${ }^{38}$ K. Merritt, J.J. Rodrigo. Clin. Orthop. Relat. Res., 326 (1996), pp. 71-79

Materials Science and Engineering: C, Vol 48 (March 2015): pg. 21-27. DOI. This article is (C) Elsevier and permission has been granted for this version to appear in e-Publications@Marquette. Elsevier does not grant permission for this article to be further copied/distributed or hosted elsewhere without the express permission from Elsevier. 
NOT THE PUBLISHED VERSION; this is the author's final, peer-reviewed manuscript. The published version may be accessed by following the link in the citation at the bottom of the page.

${ }^{39}$ M. Huber, G. Reinisch, G. Trettenhahn, K. Zweymüller, F. Lintner. Acta Biomater., 5 (2009), pp. 172-180

${ }^{40}$ S.B. Goodman. Biomaterials, 28 (2007), pp. 5044-5048

${ }^{41}$ U. Dapunt, T. Giese, F. Lasitschka, J. Reinders, B. Lehner, J.P. Kretzer, V. Ewerbeck, G.M. Hänsch. J. Transl. Med., 12 (2014), p. 74

${ }^{42}$ R. Rettig, S. Virtanen. J. Biomed. Mater. Res. A, 88 (2009), pp. 359-369

Correspondence to: M. Razavi, Biomaterials Research Group, Department of Materials Engineering, Isfahan University of Technology, Isfahan 84156-83111, Iran.

Correspondence to: L. Tayebi, School of Materials Science and Engineering, Helmerich Advanced Technology Research Center, Oklahoma State University, Tulsa, OK 74106, USA. 